\title{
Covid-19: Push to reopen schools risks new wave of infections, says Independent SAGE
}

\begin{abstract}
Jacqui Wise
London

It is not safe enough for all schools to reopen on 1 June and in pushing ahead the government is risking a new surge in cases of covid-19 in some communities, an independent committee of experts has warned. ${ }^{1}$

The Independent Scientific Advisory Group for Emergencies (Independent SAGE) has now published its full report on schools reopening after a public consultation with parents and teachers in association with The BMJ and the online forum Mumsnet. ${ }^{2}$ The report concluded that the government was ignoring the advice of its own scientists who carried out modelling showing the reproduction rate $\mathrm{R}$ rising above 1 if schools reopened.
\end{abstract}

David King, chair of Independent SAGE, said: "While we totally understand the imperative to get the nation's children back in the classroom as soon as it is safe to do so, the evidence clearly shows that the government has jumped the gun here."

On the same day that Independent SAGE published its draft report, the government released documents produced by the its official advisory body, the Scientific Advisory Group for Emergencies (SAGE) ${ }^{34}$ The documents modelled the potential impact of seven "returning to school" scenarios-all of which resulted in an increase in $R$.

SAGE said that the scale of the increase was highly dependent on the current reproduction rate and on the wider context in each community, especially adherence to social distancing. The most recent estimates for the UK are that $\mathrm{R}$ is between 0.7 and 1 , meaning that all scenarios modelled by SAGE are at risk of pushing $\mathrm{R}$ above 1 . The school reopening scenario chosen by the government is not one of those modelled by SAGE, making the potential impact of reopening even more uncertain, warned Independent SAGE.

Independent SAGE noted that since it published its draft report the government has heightened the risks of a resurgence of covid-19 cases by undermining its own messaging - a reference to the furore surrounding the government adviser Dominic Cummings who drove from London to Durham during lockdown. "Public adherence to social distancing is influenced by trust in the government and its messaging. This trust is increasingly strained, the report said.
Decisions to reopen schools must be made on a case by case basis using local real time data, and in partnership with local communities, said the report. By contrast, the government has committed to "top-down decision making without engagement." Before schools open, there should be evidence that there are low levels of covid-19 in the local community and a well functioning, coordinated, local test, track, and isolate strategy in place, said the report. "We have seen no compelling evidence that these conditions have so far been met across the country. Until they are, it is not safe to open schools everywhere on 1 June," said the committee.

Current UK data indicate that children are as likely as adults to become infected and carry the virus, but they might be less likely to transmit the virus because adults are contagious for longer than children, the report said. It warned, however, that schools could become "institutional amplifiers" of infection, if asymptomatic children went unnoticed until an adult became symptomatic. It added that there was a heightened risk of disease for families with children living in intergenerational households or who come from ethnic minority or disadvantaged backgrounds.

The report included modelling showing that delaying a school reopening by two weeks would approximately halve the risk that a child would be infected with covid-19, and delaying until September would be less risky still. It also included a risk assessment tool that provides a roadmap for schools to reopen safely. It said that this should take into account the risks to the school, the staff, the pupil, the parents, and family environment.

http://www.independentsage.org/government-failing-to-follow-own-school-advice-reviewby-independent-sage/

2 Wise J. Covid-19: Delaying school reopening by two weeks would halve risks to children, says iSAGE. BMJ 2020;369:m2079. 10.1136/bmj.m2079 32444387

Gov.uk. Scientific Advisory Group for Emergencies (SAGE): Coronavirus (COVID-19) response. 2020. https://www.gov.uk/government/groups/scientific-advisory-group-foremergencies-sage-coronavirus-covid-19-response.

4 O'Dowd A. Covid-19: Papers justifying government's plans to reopen schools are "inconclusive" say union bosses. BMJ 2020;369:m210810.1136/bmj.m2108.

Published by the BMJ Publishing Group Limited. For permission to use (where not already granted under a licence) please go to http://group.bmj.com/group/rights-licensing/ permissions 